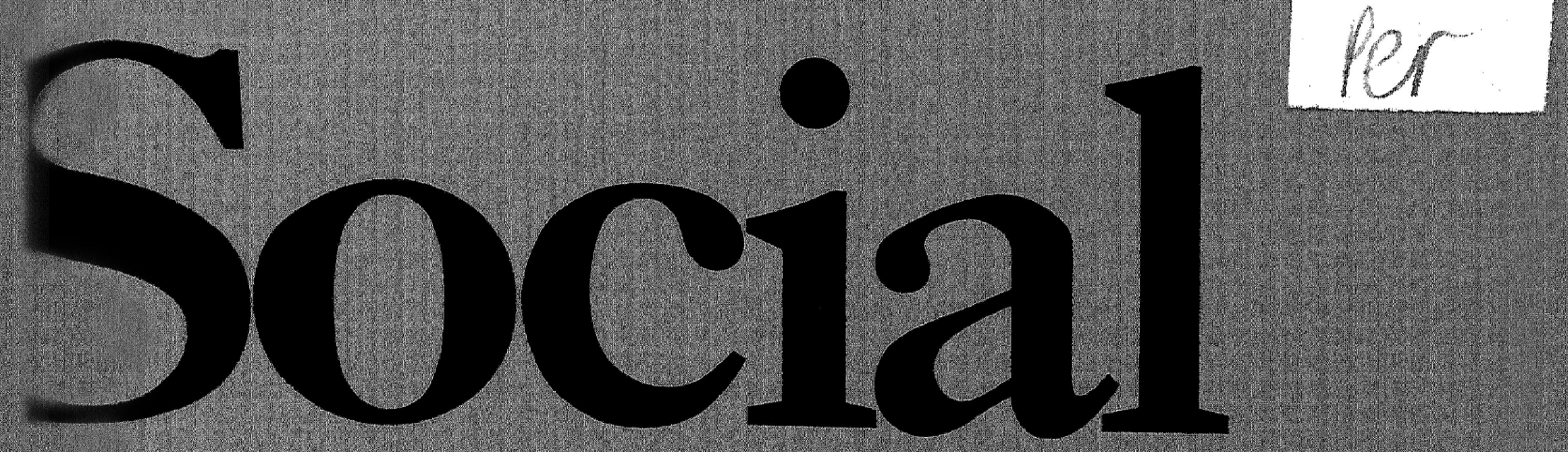

ume 22 Number 3 Fall 1998

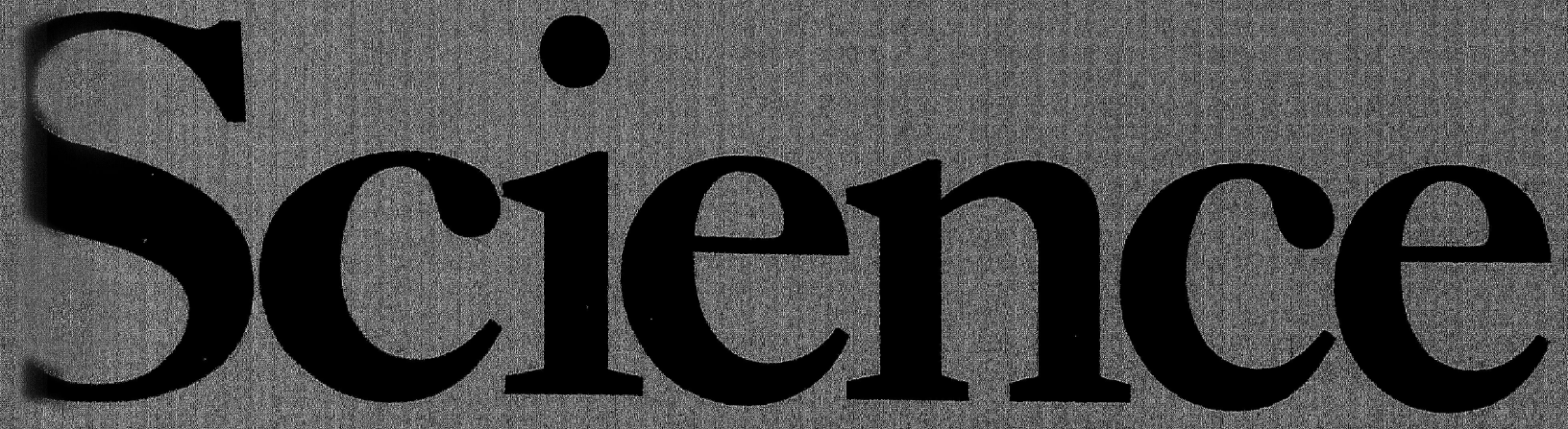

efficial journal of the Social Science History Association

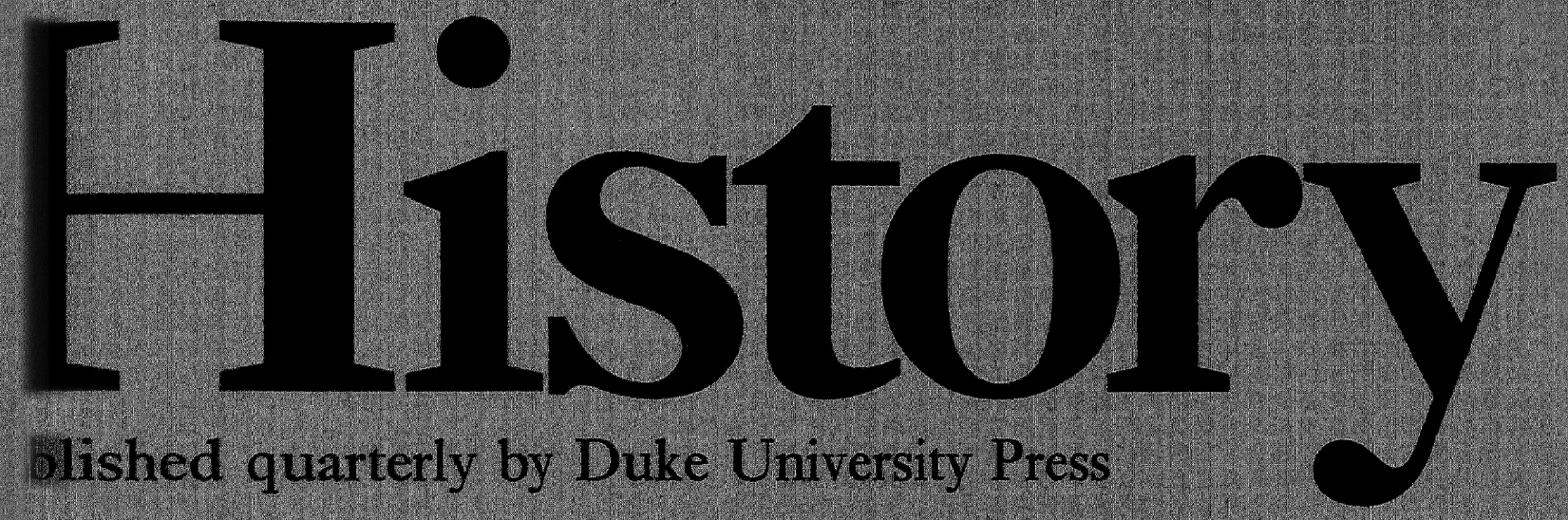

his issue: Michael D. Naragon and Marguerite Brown Introduction | rge R. Boyer The Influence of London on Labor Markets in Southern land, 1830-1914 | Joshua L. Rosenbloom The Extent of the Labor Let in the United States, 1870-1914 / Cliff Brown Racial Conflict and H Larkets: The AFL Campaign to Organize Steel Workers, J. Trent Alexander The Great Migration in Comparative $1+5,2$ $56 / 2$ 00122 40 nterpreting the Urban Origins of Southern Black Migrants to ra Pittsburgh 
Subscriptions Libraries and institutions $\$ 85$; individuals $\$ 50$; students $\$ 15$. (Add $\$ 12$ for postage outside the United States.) Individual and student rates include membership in the Social Science History Association; all such subscribers will receive information from the SSHA, as well as copies of the journal.

Recent back issues: Libraries and institutions $\$ 22$, individuals $\$ 13$; back volumes $\$ 85$. Make payment to Duke University Press, Journals Department, Box 90660, Durham, NC 27708-0660, USA. All issues more than two years old are available from Schmidt Periodicals GmbH, Ortsteil Dettendorf, D-83075 Bad Feilnbach, Germany. Please write directly to Schmidt for information and prices.

Membership inquiries should be addressed to Erik Austin, ISR, University of Michigan, 426 Thompson Street, Ann Arbor, MI 48106-1248.

Claims for missing issues should be made within two months following the regular month of publication; the publishers will supply missing numbers without charge only when losses have been sustained in transit and when reserve stock will permit. For library exchange proposals, address Duke University Library, Gift and Exchange Department, Durham, NC 27708, USA.

Photocopying Photocopies for course or research use that are supplied to the enduser at no cost may be made without need for explicit permission or fee. Photocopies that are to be provided to their end-users for some photocopying fee may not be made without payment of permission fees to Duke University Press, at two dollars per copy for each article copied.

Permissions Requests for permission to republish copyrighted material from this journal should be addressed to Permissions Editor, Duke University Press, Box 90660, Durham, NC 27708-0660.

Advertising Current rates and specifications may be obtained by writing to the Marketing Manager at Duke University Press.

Information For additional information regarding Social Science History, please contact Duke Press Journals toll free at 1-888-387-5687 (accessible within the United States) or at 919-687-3653.

Social Science History is indexed and abstracted in America: History and Life, American Bibliography of Slavic and East European Studies, Applied Social Science Index and Abstracts, Arts and Humanities Citation Index, ASCA, Current Contents, Historical Abstracts, Language and Language Behavior Abstracts, Sage Public Administration Abstracts, Sage Urban Studies Abstracts, Social Sciences Citation Index, Studies in Women Abstract, and United States Political Science Documents.

Copyright (C) 1998 by the Social Science History Association ISSN 0145-5532 


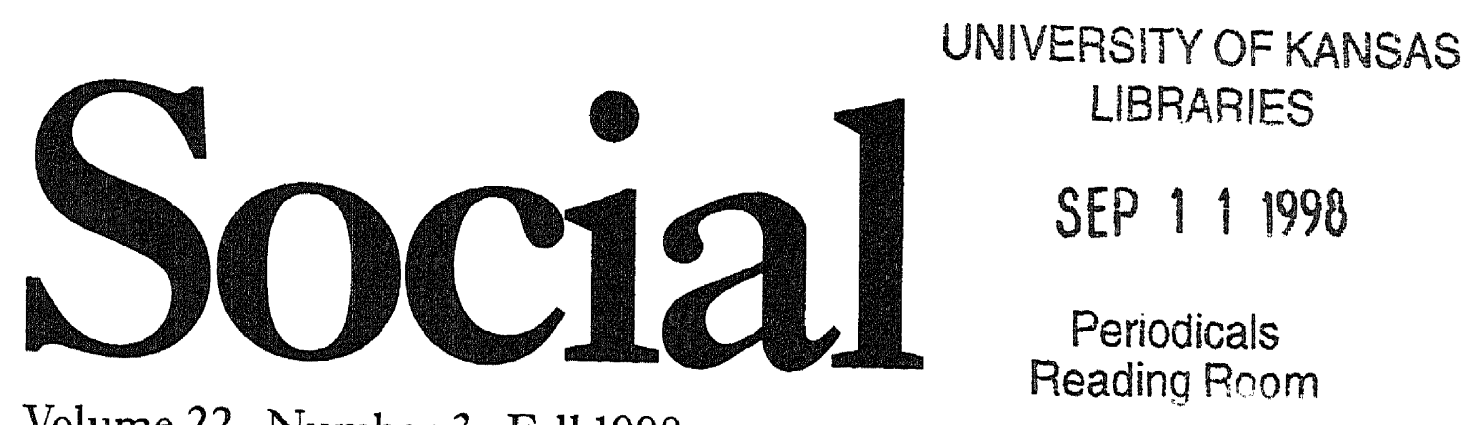

Volume 22 Number 3 Fall 1998

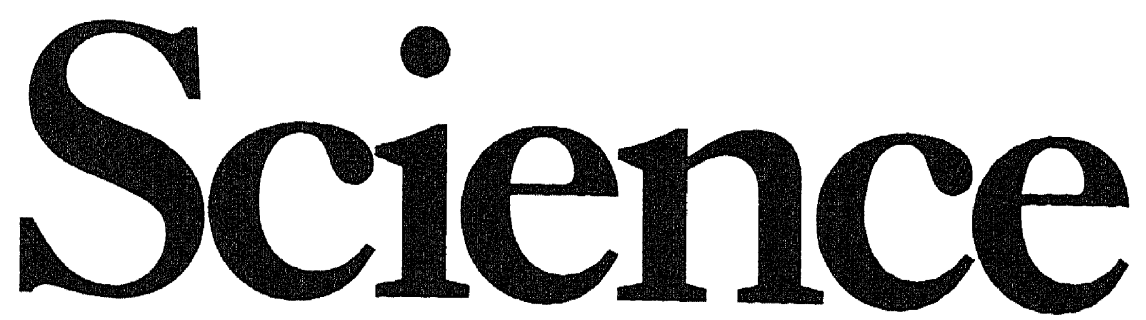

The official journal of the Social Science History Association

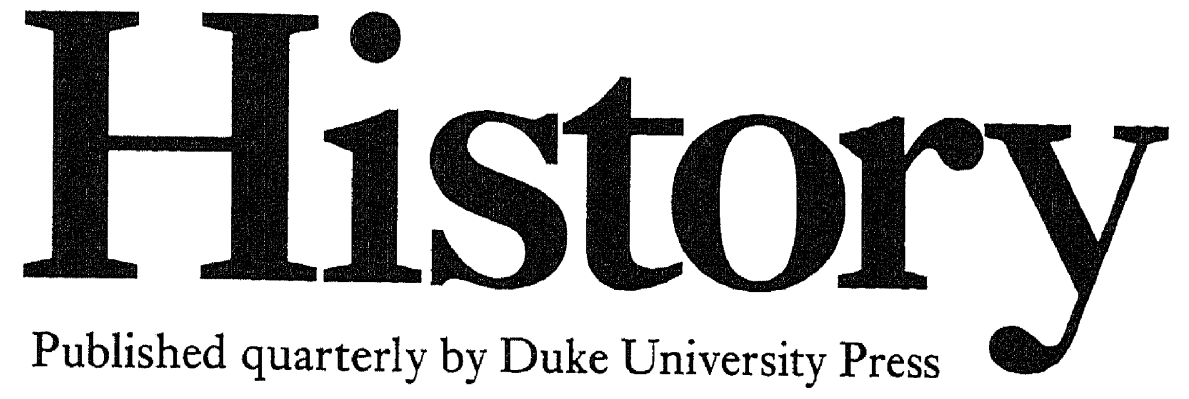


Social Science History is the journal of the Social Science History Association and exists to publish material directed to improving the quality of historical explanation in teaching and research of relevant theories and methods from the social science disciplines. It is aimed at social scientists interested in longitudinal analysis and historians seeking a more rigorous and consciously theoretical orientation. The editors encourage and provide a forum for research that attempts generalizations of some breadth verified by systematic examination of the relevant evidence and supported by quantitative analysis when appropriate. Research efforts involving comparisons across time between individuals and groups within a single population and between different and properly comparable populations across space and over time will be particularly welcome. The editors welcome contributions to the development of theory and techniques which, although firmly centered in particular social science disciplines, can provide a genuine interdisciplinary focus in approaching the historical dimension. The Social Science History Association will also inform its members about new developments in social science data archives, research funding agencies, training programs and summer institutes, and significant new publications in history and the social science disciplines through its newsletter.

Manuscripts should be submitted (four copies) to Paula Baker, Corresponding Editor, Department of History, University of Pittsburgh, 3P01 Forbes Quad, Pittsburgh, PA 15260. Include a word count on the title page. Submissions must be typed with all written material double-spaced (including quotations, notes, and the list of references) using only one side of the paper. The typewritten lines should not exceed $5 \frac{1}{2}$ inches in length. Brief parenthetical citations are included in the text, all complete references are listed alphabetically at the end of the article, and notes are used only for discursive comments and appear immediately before the list of references. Contributors may request a "Style Guide for Authors" from the editor or refer to Social Science History 18:1, pages 153-60, for detailed information on this journal's style. The Social Science History Association does not accept responsibility for statements of fact or opinion made by the contributors.

Social Science History (ISSN 0145-5532) is published quarterly, at $\$ 85$ for institutions and libraries, $\$ 50$ for individuals, and $\$ 15$ for students, for the Social Science History Association by Duke University Press, 905 W. Main St., Suite 18-B, Durham, NC 27701. Periodicals postage paid at Durham, NC. POSTMASTER: Send address changes to Duke University Press, Box 90660, Durham, NC 27708-0660. 


\author{
Joshua L. Rosenbloom
}

\title{
The Extent of the
}

\section{Labor Market in the}

\section{United States,}

1870-1914

During the late nineteenth and early twentieth centuries the spread of railroad and telegraph networks in the United States and Europe, the introduction of steamships on transatlantic routes, and the laying of transatlantic telegraph cables initiated a period of pronounced economic integration within and between countries (Williamson 1996; Thomas 1954; Chandler 1977; Perloff et al. 1965; James 1978). This period was also characterized by a rapid pace of growth and pronounced international convergence in stan-

Social Science History 22:3 (fall 1998).

Copyright $(C) 1998$ by the Social Science History Association. 
dards of living among the countries of western Europe, North America, and Australia (Maddison 1991). Jeffrey Williamson (1996) has recently argued that the increasing integration of factor markets, especially labor markets, in this era was a crucial factor in the pace of international convergence.

Since Adam Smith, economists have emphasized the benefits of broader opportunities for trade created by the geographic expansion of markets. Economic historians in particular have stressed the contribution of market expansion to economic growth. Stanley Lebergott (1964: 131), for example, concluded that "the course of American history suggests that the advance from imperfect [i.e., localized] labor markets to more perfect labor markets is one of the significant external economies that pace economic growth." Despite the important role that the expansion of labor market boundaries has played in American economic development, there has been little work that seeks to delineate the changing boundaries of labor markets over time, and even less that attempts to understand the factors determining the pace and pattern of labor market expansion. ${ }^{2}$

In this essay I offer an account and analysis of the changing geography of U.S. labor markets during the period of global economic integration that stretched from the end of the U.S. Civil War to the beginning of World War I. I argue that although the expansion of American labor market boundaries from 1870 to 1914 was impressive, it was also remarkably uneven. By the end of the nineteenth century, labor markets in the northern United States were part of a tightly integrated regional market and were, in turn, closely linked with labor markets in northern Europe. Yet this regional and international integration coincided with the persistent failure of integration between northern and southern labor markets within the United States. The importance of these results is twofold. First, they suggest that late-nineteenth-century labor market history was neither purely local nor purely national. The forces shaping the determination of wages, the evolution of wage structure, and other labor market phenomena were in some cases driven by developments outside the country altogether. Second, they show that the process of market integration was complex and historically contingent.

Falling transportation and communication costs during the late nineteenth and early twentieth centuries provided a powerful impetus for the expansion of markets, but the uneven character of market integration im- 
plies that by themselves they were not sufficient to explain increasing market integration. Rather, it was the interaction between falling transportation and communications costs and historically determined labor market institutions that shaped patterns of geographic integration. The essence of what markets do is process information and bring transactors together so that they can complete exchanges. In the absence of the Walrasian auctioneer, they must do this through humanly created institutions. As is true today, the institutional framework of late-nineteenth-century labor markets was the product of the decentralized and largely uncoordinated actions of millions of individuals. Because these actions were interdependent and subject to increasing returns, labor market integration was path-dependent and subject to the tendency to lock into certain patterns. ${ }^{3}$ Consequently, the pattern of integration that emerged in the decades after the Civil War reflected the influence of antebellum labor market conditions, and it was only as a consequence of the disruptions to labor supply and demand caused by World War I that new patterns of labor recruitment began to emerge.

\section{Measuring Market Integration}

In the half century between the Civil War and World War I, over 30 million immigrants entered the United States. This unprecedented international population movement was paralleled by equally striking internal shifts in the distribution of population within the United States due to the settlement of the frontier and the growth of cities (Eldridge and Thomas 1964). The volume of population movements does not by itself reveal much about the extent of market integration, however.

The essential characteristics of an integrated labor market are that information flows freely and quickly between job-seekers and employers at different locations and that market participants are able to respond rapidly to any imbalances in supply and demand that may emerge at a particular location. In general, however, the flow of information and the responsiveness of market participants to this information cannot be directly observed. Instead, empirical studies of market integration must rely on indirect inferences based primarily on the behavior of wages at different locations. Antoine Augustine Cournot, for example, defines the market as "the whole of any region in which buyers and sellers are in such free intercourse with 
one another that the prices of the same good tend to equality easily and quickly" (quoted in Marshall 1920: 324).

The basis for Cournot's "law of one price," as well as the difficulties encountered in applying it empirically, can be illustrated within a highly simplified model. Begin by considering a case in which two geographically distinct (but otherwise identical) labor markets are perfectly integrated with each other. ${ }^{4}$ Suppose that a single category of homogeneous labor is employed in both locations and that workers may move costlessly from one place to the other. If information about wages at each location is available to all workers, any difference in wages would induce workers in the low-wage location to migrate to the high-wage location. As the labor supply increases in the high-wage location and decreases in the low-wage location, the difference in wages will fall until real wages in the two places are precisely equalized. A corollary implication is that any shock that affects wages in one location will have an identical effect on wages in the other location.

The assumption that workers are fully informed about wages in both locations and can move costlessly between them is obviously unrealistic. In addition to the direct costs of transportation, a variety of other transaction costs are likely to affect potential migrants' location decision. These include the costs of gathering information and financing migration, as well as the psychic costs of dislocation. ${ }^{5}$ So long as these costs of moving are greater than zero, economically motivated migration will continue only until the point at which the difference in wages just equals the cost of movement. Consequently, wage equalization will not be complete, and shocks that affect wages in one location will influence wages in the other location only if they create a wage differential larger than the combined costs of movement between locations. The greater the costs of movement between locations, the less fully integrated these places will be, and the larger the range of variation in wages that will be consistent with equilibrium in the distribution of labor across locations. Thus, in equilibrium, the magnitude of the remaining wage differentials provides a lower bound measure of the costs of movement. It is this fact that makes the size of geographic wage differentials an appealing index of the extent of market integration.

It is important to recognize, however, that wage equalization by itself is neither necessary nor sufficient to establish the existence of market integration. Because potential migrants are concerned not just with income but 
with their overall well-being, wages may differ across locations with no tendency toward convergence even in a well-integrated labor market if there are significant differences in locational amenities, working conditions, or other nonwage aspects of the employment relationship. Differences in labor force composition across locations can also produce persistent differences in observed average wages. These measurement problems cannot be eliminated, but it is possible to minimize their impact by making wage comparisons within relatively homogeneous groups of workers and controlling for geographic differences in the cost of living and other factors likely to influence well-being. Persistent supply or demand shocks can also produce the appearance of persistent wage differences despite substantial supply responses within a well-integrated market. But under these circumstances the supply response to these shocks should be manifested in a positive correlation between population movements and observed wage differentials. On the other hand, it is possible for wage equalization to occur by accident within two entirely distinct labor markets, but such an event is unlikely to persist over a long period within a dynamic economy. ${ }^{6} \mathrm{It}$ is also possible for trade in goods and other factors of production to substitute for labor mobility, producing wage equalization without labor market integration. But the importance of this theoretical possibility seems limited in the late nineteenth and early twentieth centuries.

\section{Was There a National Labor Market in the United States?}

Most research on geographic wage differentials within the United States has focused on analyzing the results of a small number of late-nineteenthcentury studies that collected payroll data from samples of employers in a variety of locations. These include the Weeks and Aldrich Reports (U.S. Congress 1886, 1892), Bulletin 18 of the Department of Labor (U.S. Department of Labor 1898), and the Nineteenth Annual Report of the Commissioner of Labor (U.S. Department of Commerce and Labor 1905). The advantage of the data contained in these studies is that they permit comparisons of wage rates across locations for specific occupations, thus controlling for potential heterogeneity in human capital and working conditions that could otherwise produce spurious variations. Against this advantage, however, must be 
weighed the limited chronological and geographic coverage of these surveys, as well as the small size and possibly unrepresentative composition of the samples on which they rest. Wage data are available only for occupations sufficiently ubiquitous to be found in a large number of locations. Consequently, most of the wage quotations refer to skilled craft workers engaged in production for local markets. Even so, the available figures often rest on small samples of employers and workers and cover a restricted, and in some cases changing, sample of locations and years. ${ }^{7}$ The principal alternative to the occupational wage data is average factory earnings calculated from the census of manufacturers. Average factory earnings cover a much larger segment of the labor force and are available for 100 or more cities at each census date beginning in 1880 . But because they are an average over possibly heterogeneous groups of workers, it is more difficult to control for the effects of labor force composition on wages.

Clearly, neither source of data is perfect, but their imperfections are different, and they point to substantially similar conclusions. Reflecting the more rapid pace of economic growth in the North Central region, wages there remained higher than in the Northeast throughout the pre-World War I era. Although the East-West differential was relatively large as late as 1870 , within the northern part of the country there was a very rapid convergence, suggesting the emergence of a substantially unified labor market across the Northeast and North Central regions before the end of the century. Wages in the Mountain and Pacific regions remained higher than those in the Northeast and North Central regions despite substantial population flows into this area, suggesting that the growth of demand simply outpaced the ability of the market to respond to this disequilibrium.

Within the South, a similar East-West wage gradient is also apparent. In the 1870 s and 1880s wages in the West South Central region were equal to or greater than northern wages, while wages in the South Atlantic were below northern levels. Wages throughout the South declined relative to those in the North after 1870 , resulting in a widening North-South wage gap at the same time that wages across the South were becoming more equal. Despite declining southern wages, rates of out-migration from the region remained extremely low until the 1910s. Thus, it appears that regional integration within the North and South coincided with the persistent isolation of the two regions.

The earliest data on regional variation in occupational wage rates are 


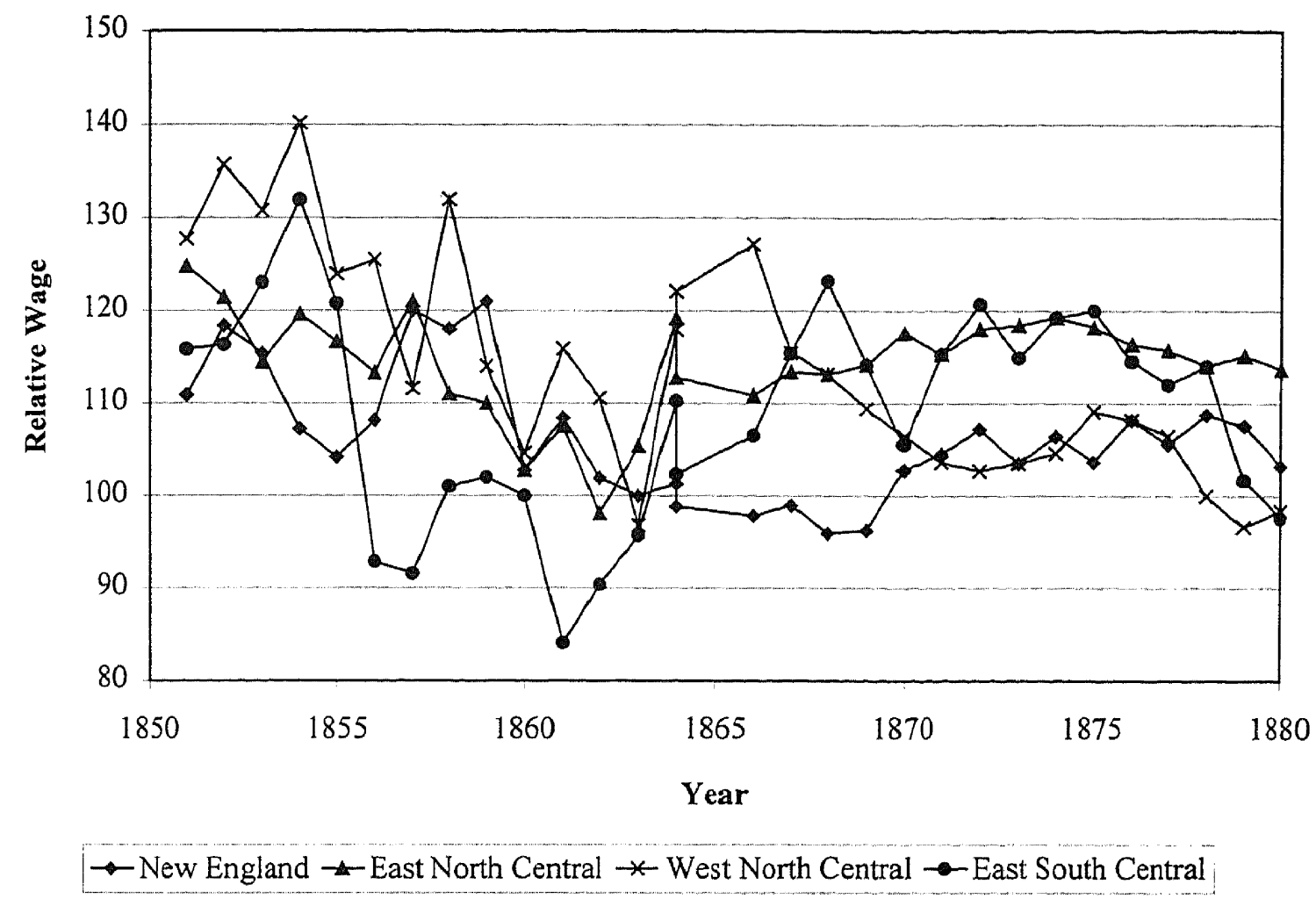

Figure 1 Relative regional real wages of common labor, 1851-1880 (Middle Atlantic $=$ 100 in each year)

Source: Coelho and Shepherd 1976.

contained in the Weeks Report. Conducted as a special supplement to the 1880 census, the report gathered data on wages and prices extending back to 1850 or earlier from 627 manufacturing, mechanical, and mining firms in 38 states, 2 territories, and the District of Columbia. Although data were collected from all parts of the country, $83 \%$ of the employers surveyed were concentrated in the Northeast and North Central regions. In addition, because the data were collected retrospectively, the number of observations declines sharply in the earlier years. Philip Coelho and James Shepherd (1976) used these data to examine regional differences in real wages from 1851 to 1880 for common laborers and engineers - the two most numerous occupations in the data - as well as to construct a combined regional index based on wages for six occupations. ${ }^{8}$

Figure 1 plots Coelho and Shepherd's estimates of wages of common laborers adjusted for regional differences in retail prices in New England and the East North Central, West North Central, and East South Central regions as a percentage of the wage in the Middle Atlantic. Because of the 
small number of observations available, they do not report real wages for the South Atlantic and other regions. Within the North a clear tendency toward wage convergence is apparent. ${ }^{9}$ In the early 1850 s real wages in the North Central region were $20 \%$ to $30 \%$ higher than those in the Middle Atlantic, while wages in New England were from 10\% to 20\% above those in the Middle Atlantic. By the early 1860s wages in New England had fallen to near equality with those in the Middle Atlantic, and wages in the West North Central appear to have converged shortly after the end of the Civil War. Although wages in the East North Central remained above eastern levels, the wage gap was clearly smaller in the 1870 s than it had been in the 1850 s. In the one southern region, wage behavior was more erratic: Wages fluctuated widely around the level of those in the Middle Atlantic, with no clear trend.

Two sources - the Aldrich Report and the Nineteenth Annual Reportare available for $1890 . .^{10}$ Although differences in geographic coverage between these sources and the Weeks Report mean that wage differentials for 1890 cannot be directly compared to those based on the Weeks Report, both sources suggest that within the North convergence continued over the next decade. Table 1 shows real wages for a number of occupations in each region as a percentage of the wage level of the corresponding occupation in the Middle Atlantic based on Coelho and Shepherd's (1979) analysis of regional wage and price data from the Aldrich Report. Although relative wages varied across occupations, wages in New England and the East and West North Central regions were generally within $5 \%$ to $10 \%$ of those in the Middle Atlantic by 1890 . In contrast, wages farther west-in the Mountain and Pacific regions - remained $15 \%$ to $25 \%$ above eastern levels.

The data for the South present a more complicated picture. The South Atlantic was clearly a low-wage region for all types of labor. In just two occupational categories - machinists and iron molders - were wages in the South Atlantic equal to or above those in the Middle Atlantic, and the median occupational wage ratio was just $83 \%$. Generally, the interregional differentials were largest for laborers and other unskilled workers and smallest among skilled workers, especially those in the metal trades. The same occupational pattern is apparent in the South Central regions, where wages of skilled occupations equaled or exceeded those in the Middle Atlantic, while those of unskilled laborers lagged behind northern levels. In the East South Central region, laborers' wages, which Figure 1 shows had been nearly equal 
Table 1 Relative regional real wages for selected occupations in 1890 from the Aldrich Report (Middle Atlantic = 100 for each occupation)

\begin{tabular}{lrrrrrrrr}
\hline Occupation & NE & ENC & WNC & SA & ESC & WSC & MTN & PAC \\
\hline Blacksmith & 94 & 94 & 104 & 89.5 & 105 & 113 & 115 & 113 \\
Machinist & 92 & 103 & 106 & 103 & 114 & 143 & 113 & 115 \\
Iron molder & 87 & 105 & 103 & 104 & 107 & 119 & 117 & 123 \\
Tinsmith & 82 & 96 & 100 & 96 & 102 & 111 & 121 & 112 \\
Carpenter & 93 & 94 & 96 & 81.6 & 101 & 122 & 117 & 94 \\
Mason & 91 & 109 & 104 & 84 & 111 & 114 & 122 & 130 \\
Painter & 80 & 92 & 94 & 70 & 94 & 103 & 110 & 103 \\
Bricklayer & 82 & 102 & 103 & 79 & 109 & 97 & 119 & 123 \\
Plumber & 103 & 105 & 122 & 91 & 121 & 112 & 125 & 121 \\
Baker & 104 & 114 & 114 & 90 & 114 & 105 & 95 & 134 \\
Cabinetmaker & 92 & 85 & 98 & 82 & 100 & 109 & 116 & 94 \\
Stonecutter & 86 & 108 & 111 & 80 & 102 & 114 & 119 & 114 \\
Common laborer & 101 & 108 & 110 & 67 & 79 & 100 & 148 & 121 \\
Farm laborer & 126 & 114 & 123 & 67 & 78 & 90 & 124 & 129 \\
Median regional wage ratio & 92 & 103 & 104 & 83 & 104 & 112 & 118 & 118 \\
\hline
\end{tabular}

Sources: Relative real wages are computed from Coelho and Shepherd 1979: 77. Occupational wages are from the Aldrich Report, with the exception of farm labor wages, which are from the USDA.

Note: NE = New England; ENC $=$ East North Central; WNC = West North Central; SA = South Atlantic; ESC $=$ East South Central; WSC $=$ West South Central; MTN $=$ Mountain; PAC $=$ Pacific.

to those in the Middle Atlantic in 1880, were $20 \%$ below northern levels by 1890 . In the West South Central region, laborers' wages were comparable to those in the North, but the wages of agricultural laborers were just $90 \%$ of those in the Middle Atlantic states. Overall, the impression is that southern wages were falling increasingly below northern levels and that the downward pressure was most intense on less skilled workers.

The analysis William Sundstrom and I (1993) performed on wage data from the Nineteenth Annual Report closely parallels Coelho and Shepherd's results. Table 2 shows relative regional real wages for each of the eight occupations they consider. Wages in the North Central region and the Northeast were approximately equalized, while wages in the West remained $15 \%$ to $25 \%$ above eastern levels. Wages in the Southeast were again consistently lower than those in the North, with the differential greatest for unskilled labor, while wages in the South Central region were relatively high for skilled workers but below northern levels for unskilled labor.

Wage data in Bulletin 18 covering 23 occupations in 12 cities from 
Table 2 Relative regional real wages of selected occupations in 1890 from the Nineteenth Annual Report of the Commissioner of Labor (Northeast $=100$ for each occupation)

\begin{tabular}{lcccc}
\hline Occupation & North Central & Southeast & South Central & West \\
\hline Bricklayer & 110 & 63 & 117 & 138 \\
Carpenter & 99 & 71 & 102 & 116 \\
Hod carrier & 104 & 62 & 91 & 128 \\
Machinist & 103 & 100 & 125 & 115 \\
Iron molder & 105 & 92 & 117 & 118 \\
Pattern maker & 104 & 88 & 110 & 110 \\
Common laborer, building & 107 & 53 & 92 & 116 \\
$\begin{array}{l}\text { Common laborer, foundry } \\
\text { and machine shop }\end{array}$ & 106 & 74 & 99 & 120 \\
$\begin{array}{l}\text { Median regional relative wage } \\
\text { ratio }\end{array}$ & 105 & 73 & 106 & 117 \\
\hline
\end{tabular}

Source: Relative real wage ratios are computed from Sundstrom and Rosenbloom 1993: 386.

1870 to 1898 provide information on a consistent sample of locations and occupations spanning the gap in coverage between the Weeks Report and the Aldrich and Nineteenth Annual Reports. Contrary to the convergence of northern wages suggested by these other sources, however, in Rosenbloom 1990a I reported that throughout the three decades from 1870 to 1898 real wages in the four midwestern cities included in the data remained roughly $20 \%$ to $25 \%$ above wages in the five northeastern cities covered. Only two southern cities - Richmond and New Orleans - and one western city-San Francisco - were included in the data. Wage data for these cities are consistent with the patterns of interregional variation indicated by other sources. Wages in Richmond diverged from the northeastern levels, dropping from $85 \%$ to $81 \%$ of wages in the Northeast, while wages in New Orleans were approximately equal to those in the Northeast. Wage rates in San Francisco began much higher than those in the East, but the West-East wage gap narrowed over time, declining from $36 \%$ in the 1870 s to $15 \%$ by the late 1890 s.

It is not possible to offer a conclusive explanation for the discrepancy in the magnitude of the East-Midwest wage gap implied by Bulletin 18 and the other wage studies. It seems likely, however, that the difference between the studies reflects the peculiar sampling procedures used to assemble the 
Bulletin 18 data and the small sample sizes on which most observations were based. Like the Weeks Report, the Bulletin 18 wage data were collected retrospectively, but to maintain a consistent sample over the 1870-98 period, investigators collected data only from employers who had been in existence and had payroll records for the entire period being considered. Since both the Aldrich and Nineteenth Annual Reports are based on larger, more representative, and presumably more reliable samples, it seems likely that the interregional wage gap implied by the Bulletin 18 data for the $1890 \mathrm{~s}$ is a statistical anomaly.

Average factory earnings data analyzed in Rosenbloom 1996 provide a largely independent test of conjectures based on the occupational wage data. Covering many more places and a much broader segment of the labor force, they reinforce conclusions based on the wage data, while making it possible to extend comparisons to many more cities and over a much longer time period. Beginning with the 1880 census, collection of industrial statistics in major cities was turned over to special agents knowledgeable about manufacturing conditions in their districts. The quality of the resulting returns is generally regarded as substantially higher than that of the manufacturing returns collected for other areas by regular census enumerators. From the published census volumes it is possible to calculate the average earnings of adult male wage earners in a consistent sample of 100 cities for each census year from 1879 to $1919 .{ }^{11}$ Figure 2 shows that as early as 1879 real average earnings were nearly equalized across New England and the Middle Atlantic and East North Central regions. Although earnings in the West North Central region were substantially higher than those in the East in 1879 , they converged rapidly (though not completely) toward equality. In the South Atlantic region, earnings, which began $16 \%$ below those in the Middle Atlantic states, diverged steadily, so that by 1914 the gap had risen to $26 \%$. In the South Central region, earnings began higher than they did in the Middle Atlantic states but had fallen slightly behind by 1889. This gap continued to widen, reaching $14 \%$ by 1914 , resulting in a convergence of wage levels within the two southern regions.

Because census earnings data are an average over possibly heterogeneous groups of workers, differences in labor force composition across cities could in principle affect the interregional comparisons shown in Figure 2. In practice, the extent of any such effect seems limited. During the late 


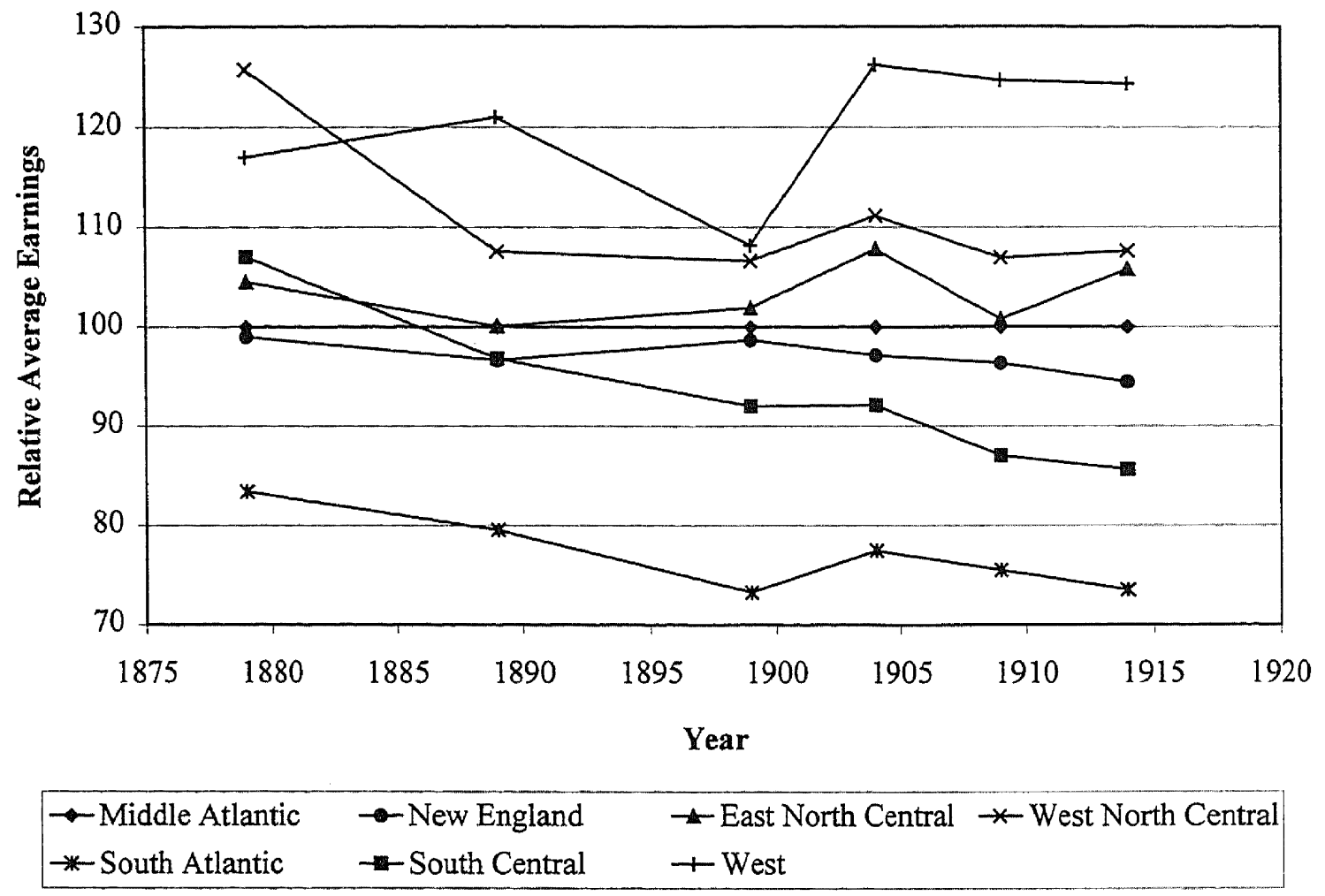

Figure 2 Relative regional real earnings of male factory wage earners, 1879-1914 (Middle Atlantic $=100$ in each year)

Source: Rosenbloom 1996.

nineteenth century technological changes in manufacturing were promoting the increasing homogenization of the factory workforce (Goldin 1990: 115; Gordon et al. 1982: 79-100). Moreover, in Rosenbloom 1996 I show that controlling for broad differences in occupational composition as well as the age structure and literacy of the labor force actually tends to reinforce the pattern of interregional differentials; interregional variation is reduced within the North, while the North/South earnings gap is increased slightly.12

The census earnings data can also be used to examine the extent of wage equalization within regions. Table 3 reports one widely used measure of within-region dispersion, the coefficient of variation of earnings. ${ }^{13}$ In 1879 the greatest dispersion of earnings occurred within the two southern regions, where the coefficient of variation was greater than 0.3 , roughly 2 to 3 times as large as for any of the other regions. In both the South Atlantic and South Central regions, however, dispersion fell sharply, indicating that substantial within-region equalization coincided with the increasing integration of the two southern regions. In the North, there is more limited evidence of 
Table 3 Within-region coefficient of variation of real average earnings of male manufacturing wage earners, 1879-1919

\begin{tabular}{lccccccc}
\hline Region & 1879 & 1889 & 1899 & 1904 & 1909 & 1914 & 1919 \\
\hline MA & 0.124 & 0.133 & 0.086 & 0.081 & 0.077 & 0.073 & 0.086 \\
NE & 0.149 & 0.117 & 0.104 & 0.116 & 0.114 & 0.112 & 0.092 \\
ENC & 0.068 & 0.094 & 0.064 & 0.089 & 0.079 & 0.104 & 0.108 \\
WNC & 0.118 & 0.117 & 0.100 & 0.086 & 0.085 & 0.101 & 0.077 \\
SA & 0.304 & 0.204 & 0.236 & 0.196 & 0.197 & 0.125 & 0.148 \\
SC & 0.325 & 0.173 & 0.147 & 0.158 & 0.108 & 0.097 & 0.086 \\
West & 0.058 & 0.072 & 0.092 & 0.047 & 0.078 & 0.054 & 0.090 \\
\hline
\end{tabular}

Source: From Rosenbloom 1996: Table 3.

Notes: $\mathrm{MA}=$ Middle Atlantic; NE $=$ New England; $\mathrm{ENC}=$ East North Central; $\mathrm{WNC}=$ West North Central; SA = South Atlantic; SC = South Central. The coefficient of variation is calculated as the ratio of the standard deviation of earnings to the real average level of earnings across all cities for which data are available in each region at each date.

within-region convergence; in both New England and the Middle Atlantic region, dispersion fell over time, approaching levels comparable to those in the North Central region.

Both wage and earnings data suggest that a well-integrated northern labor market capable of achieving a substantial redistribution of population without producing large or lasting wage differentials emerged in the decades immediately following the Civil War. This market did not, however, extend to the Far West or the South. Despite relatively large population movement into the West, wages and earnings in this region remained higher than those in the East (Eldridge and Thomas 1964: 117-20). The combination of high rates of migration and continued wage differentials suggests that the rapid pace of labor demand growth in this region simply outstripped the ability of the labor market to respond. In the South, despite substantial population movements from the low-wage South Atlantic region toward higher-wage areas in the South Central states and an impressive within-region convergence, wages and earnings fell further behind those in northern regions, especially for less skilled labor, without inducing any significant migration northward. By 1890 wages of unskilled laborers in the South Atlantic and East South Central regions were well below those in the North, while West South Central wages had reached equality with northern wages. Thereafter, the census earnings data imply a continuing decline in relative real wages 
until at least 1914. Wages for skilled workers throughout the South were relatively higher in 1890 , but without data for subsequent years it is unclear whether this reflects a greater degree of North-South integration in markets for more skilled labor, or simply a difference in the relative regional supply and demand of skilled versus unskilled workers. Compared both to the degree of equalization achieved within the North and to the magnitude of transatlantic wage differentials considered below, the North-South wage gap that had emerged by the turn of the century appears relatively large.

Low wage levels in the South Atlantic states did encourage substantial out-migration, but almost all of this labor movement was directed toward the South Central region of the country until the outbreak of World War I. Hope Eldridge and Dorothy Swaine Thomas (1964: 90) calculated that decadal rates of net migration from the South as a whole fell from 20 per thousand in the 1880 s to around 10 per thousand in the two decades after 1890. These rates are well below those found in many European countries at this time. Only after 1910 did the rate of out-migration begin to accelerate, quadrupling to 42 per thousand in the 1910 s, then rising to 48 per thousand in the 1920s.

\section{International Labor Market Integration}

Undoubtedly the more than 50 million people who emigrated from Europe to labor-scarce regions in the Americas and Australasia between 1860 and 1914 were responding to a wide variety of different influences. But it is also apparent that economic forces were a central factor in directing these unprecedented population movements. ${ }^{14}$ Harry Jerome (1926) noted that yearto-year variations in immigration to the United States closely paralleled the business cycle, while a number of studies have shown that immigrant destinations within the United States were influenced by across-state variations in per capita income (Dunlevy and Gemery 1978; Dunlevy 1980; Dunlevy and Saba 1992). Within Europe, rates of emigration varied widely across countries and over time (see Table 4), and the reasons for this variation have been the subject of considerable study. ${ }^{15}$ Timothy Hatton and Jeffrey Williamson's (1994b) regression analysis of decadal average emigration rates from 11 European countries shows that close to three-quarters of the variation in emigration rates can be explained by a small number of economic and 
Table 4 European emigration rates by decade, selected countries, 1871-1910 (per 1,000 mean population)

\begin{tabular}{lcccc}
\hline Country & $1871-80$ & $1881-90$ & $1891-1900$ & $1901-10$ \\
\hline British Isles & 50.4 & 70.2 & 43.8 & 65.3 \\
Belgium & - & 8.6 & 3.5 & 6.1 \\
France & 1.5 & 3.1 & 1.3 & 1.4 \\
Germany & 14.7 & 28.7 & 10.1 & 4.5 \\
Netherlands & 4.6 & 12.3 & 5.0 & 5.1 \\
Denmark & 20.6 & 39.4 & 22.3 & 28.2 \\
Ireland & 141.7 & 88.5 & 69.8 & - \\
Norway & 47.3 & 95.2 & 44.9 & 83.3 \\
Sweden & 23.5 & 70.1 & 41.2 & 42.0 \\
Italy & 10.5 & 33.6 & 50.2 & 107.7 \\
Spain & - & 36.2 & 43.8 & 56.6 \\
\hline
\end{tabular}

Source: Hatton and Williamson 1994a: 7.

demographic factors. In particular, they find a strong positive relationship between emigration rates and the wage gap between sending and receiving regions. Other important explanatory variables include the rate of population growth 20 years in the past, the share of the labor force in agriculture, and the stock of past emigrants living abroad. Higher lagged population growth raised the proportion of the population in the prime emigration age group and may have reduced the chances to acquire land, while declining agricultural employment may reflect the disruptive impact of industrialization on domestic agricultural labor markets. The stock of previous migrants was important both as a source of information about opportunities abroad and as a means of financing emigration.

To assess the extent to which these population movements reflect transatlantic labor market integration, it is necessary to look at the magnitude of international real wage differentials. Fortunately, several recent studies have attempted to make such comparisons for the late nineteenth and early twentieth centuries. The most extensive comparison is offered by Jeffrey Williamson (1995), who has constructed a data set of internationally comparable real wages from 1830 to the present for 11 European and 4 New World countries. Williamson's data are intended to reflect national averages, but judging from his sources for the United States it would be most appropriate to view his wage series as a measure of labor market conditions 


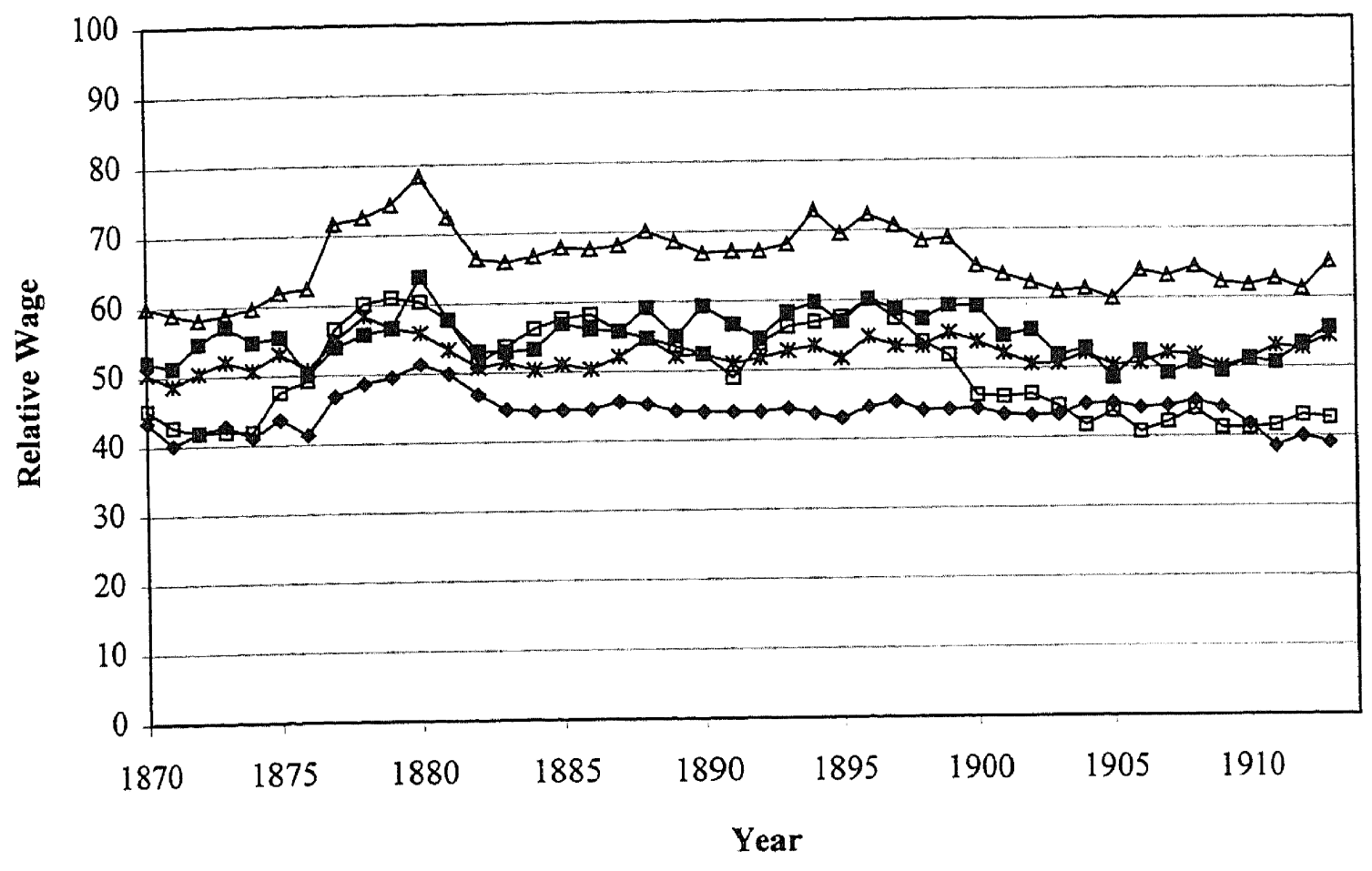

$\rightarrow$ Belgium $\rightarrow$ France $\rightarrow$ - Germany $\triangle$ Great Britain $\square-$ Netherlands

Figure 3 Relative international real wages, 1870-1913 (U.S.A. = 100 in each year) Source: Williamson 1995.

in the Northeast and North Central regions. Wage rates in each country refer to unskilled labor. They are deflated by national cost-of-living series and then converted to internationally comparable levels using purchasingpower-parity price indices calculated at benchmark dates. As Williamson (1995) demonstrates, the period from 1870 to 1913 was one of pronounced international wage rate convergence, explained in large part by reductions in the wage gap between the New World and the Old. ${ }^{16}$

To understand what this convergence meant for American labor markets, however, it is useful to look more closely at the gap between wages in the United States and each of the European countries in Williamson's data. Two kinds of behavior are apparent. In the first group of countries (Great Britain, Germany, France, Belgium, and the Netherlands), despite substantial short-run fluctuations, the wage gap with the United States remained relatively stable. Figure 3 graphs wages in each of these countries relative to those in the United States from 1870 to 1913 . Among these countries, wage levels were highest in Great Britain, fluctuating between $60 \%$ and $70 \%$ of 
The Extent of the Labor Market in the United States, 1870-1914 303

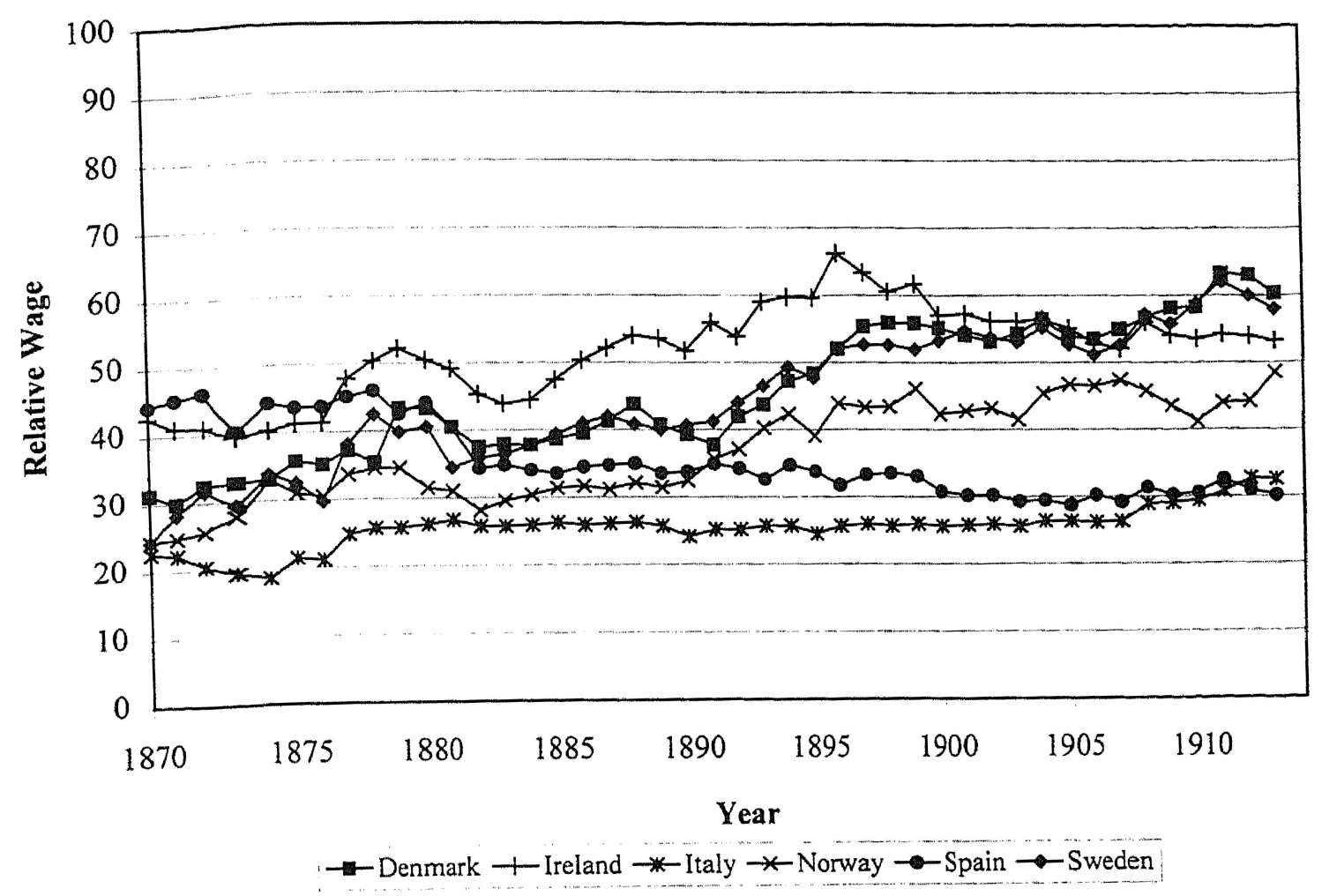

Figure 4 Relative international real wages, 1870-1913 (U.S.A. $=100$ in each year) Source: Williamson 1995.

American wages, and lowest in France, where wages were between $40 \%$ and $50 \%$ of those in the United States. The persistence of these gaps suggests that they reflect a relatively stable equilibrium situation. Indeed, as Table 4 shows, emigration rates from most of the countries shown in Figure 1 were quite low after 1870, implying that the remaining wage gaps created little incentive for transatlantic immigration. Only British emigration rates remained relatively high, suggesting that the wage gap may overstate the transaction costs in this case.

In the second group of countries (Ireland, Denmark, Norway, Sweden, and Italy) wage levels were converging toward those in the United States. Wage ratios for these countries and for Spain, where wages actually diverged from the United States, are graphed in Figure 4. In three of these countries-Ireland, Sweden, and Denmark - wage ratios reached levels only slightly below those in Great Britain by the early 1890 s, then leveled off. Convergence in Norway and Italy was slower and less complete. For all of these countries we seem to be observing a process of gradual ad- 
justment toward equilibrium. Consistent with this view, Table 4 shows that the emigration rates from these countries were higher than for the countries with stable wage gaps.

In another recent study of international labor market integration, Robert Allen (1994) compared real wage levels in the English-speaking world from 1880 to 1913. Allen compiled wages for unskilled laborers and bricklayers, as well as average factory earnings for six cities in England, Canada, the United States, and Australia. English wages were below those in all three New World countries, consistent with the outflow of labor from England, but the magnitude of these differentials varied substantially, indicating that migration streams were not very responsive to differences in economic incentives across destinations. Allen also found that differentials varied substantially by skill level. Comparing British and American real wages, he concluded that the real wages of unskilled labor were essentially equalized across the two countries but that the wages of bricklayers and average factory earnings in the United States were roughly twice what comparable workers in Britain earned. Peter Shergold's (1983) comparison of real wages in Pittsburgh, Pennsylvania, and Birmingham, England, in the early 1900s similarly found that wage gaps increased with skill level, rising from near equality among unskilled workers to a range of $50 \%$ to $100 \%$ for the most skilled workers.

Together wage and migration data point to the emergence and extension of an increasingly well integrated transatlantic labor market in the decades after the U.S. Civil War. ${ }^{17}$ The persistence of wage gaps between Europe and the United States indicates that transaction costs in international labor markets remained, but whether one views the resulting differentials as "large" or "small" is a matter of judgment. In comparison with wage differentials within the Northeast and North Central United States, the Europe-America wage gaps were relatively large, but relative to the North-South gap in unskilled labor wages, the transatlantic wage differential does not appear especially large. The high levels of immigration from Ireland and Scandinavia and the marked convergence of wages in these countries toward U.S. levels point to an impressive expansion of the scope of transatlantic labor markets at this time. Meanwhile, the stability of long-run wage differentials between the United States and other countries of northwestern Europe despite short-run fluctuations suggests that American employers faced a relatively elastic international supply of labor. 


\section{Labor Market Institutions}

\section{and Labor Market Integration}

Clearly, labor market integration over long distances was possible by the late nineteenth century. Within the Northeast and North Central regions of the United States, substantial population redistributions were accomplished with only relatively small wage differentials. Meanwhile, population movements within the American South were substantially reducing wage differentials within and between regions. Although the larger cost of transatlantic migration prevented the equalization of American and European wages, international labor market integration was sufficient to equalize the long-run trend in wage growth in the United States and the countries of northwestern Europe. Moreover, the high levels of emigration from Ireland, Scandinavia, and later Italy and the corresponding increase in relative wages in these countries suggests that the boundaries of international labor markets were expanding in the late nineteenth and early twentieth centuries.

But the pattern of integration was uneven. At the same time that labor markets across the Northeast and North Central United States were becoming part of a unified regional and international market, and labor markets throughout the South were becoming increasingly integrated, the persistence and growth of the North-South wage gap suggests that these regions remained largely isolated from one another. The persistent NorthSouth wage gap in the post-Civil War period is presumably a reflection of the presence of substantial costs of movement or communication that inhibited labor supply adjustments..$^{18}$ But in light of the evidence of substantial intraregional and international integration at this time, we must confront this question: Why did such large costs of movement and/or communication exist between North and South? Clearly, there was nothing inherent in the available transportation and communication technologies that would have prevented a greater degree of integration between northern and southern labor markets. ${ }^{19}$

To account for the persistent North-South wage gap and the absence of substantial interregional migration in response to this differential prior to World War I, it is necessary either to argue that the observed gap overstates the economic incentives or to identify the factors that contributed to large costs of movement and communication between North and South. I 
believe that the most compelling explanation for the uneven and selective pattern of labor market integration during the late nineteenth and early twentieth centuries is to be found in an examination of the institutional structures that facilitated the flow of information between employers and workers and provided them with the resources needed to complete transactions. ${ }^{20}$ Because these institutions were the product of decentralized but interdependent decisions made by millions of job-seekers and employers and were subject to important economies of scale, they were prone to evolve in a path-dependent manner, which can only be understood by examining the historical circumstances in which they were formed.

Networks of friends and relatives were the principal channels of communication and assistance in late-nineteenth- and early-twentieth-century labor markets. The predominance of "chain migration," in which earlier migrants from a particular community were followed by later migrants, has been widely noted by historians and economists studying population movements in this period. ${ }^{21}$ According to Charles Tilly (1990: 84), "the effective units of migration were (and are) neither individuals nor households but sets of people linked by acquaintance, kinship, and work experience." Not only could friends and family provide accurate information about employment opportunities at little cost; they were often in a position to provide funds to help finance migration and to assist in the process of adaptation to a new environment (Ben-Porath 1980; Hareven 1982). In 1868 the New York Times (2 February: 4) observed that "when the demand for help is fair and wages are good, a brisk business is done at the offices of the emigrant lines of passenger ships in receiving the money of servant girls, mechanics and laborers, to prepay the cost of bringing hither other members of their family." In 1880 the representative of one transatlantic steamship company estimated that perhaps $30 \%$ to $40 \%$ of German immigrants were traveling on tickets prepaid by someone already in the United States. By the early twentieth century it was estimated that $60 \%$ of immigrant arrivals were traveling on prepaid tickets and that nearly $80 \%$ had a relative waiting for them (Rosenbloom 1988: 21; Morawska 1990: 194; Kamphoefner 1987: 188). The importance of family and friends did not stop with long-distance migration. The workings of local labor markets are harder to observe, but all of the available evidence suggests that friends and family were among the most 
important sources of labor market information within as well as between locations. ${ }^{22}$

The importance of kin and friendship networks in the labor market reflects their advantages for employers as well as job-seekers. ${ }^{23}$ For employers, referrals by their current workers were a low-cost method of labor recruitment that also served as a screening mechanism and ensured that newly arrived workers would have someone to assist in their training and assimilation into the workforce (Hareven 1982). Consequently, employers actively encouraged chain migration and in some instances even advanced money for travel costs, money that would then be repaid from future earnings (Rosenbloom 1994: 389).

Once a particular migration stream had been initiated, kin and friendship networks were a highly effective means of mobilizing labor. Because the connections established in this way linked specific sending and receiving regions, they offer a partial explanation for the selective and uneven patterns of integration observed during the late nineteenth and early twentieth centuries. But chain migration by itself is not sufficient to account for the pattern of labor market integration. As the locations of economic activity shifted and additional sources of labor supply emerged, new streams of migration were continually being initiated. The key question is why the processes responsible for creating these new connections within the labor market operated selectively and unevenly.

When the referrals of current employees and direct applications of jobseekers proved inadequate, employers were obliged to recruit labor directly. Employers located in or near urban areas might simply dispatch a foreman to nearby immigrant communities to recruit additional workers. For more isolated employers, however, it was necessary to search farther afield, and even employers in urban areas sometimes found the local labor supply inadequate for their needs. As my 1994 article "Looking for Work, Searching for Workers" (388-91) documents, when northern employers were unable to obtain the labor they needed through the referrals of their current employees or from the locally available pool of job-seekers, they either dispatched their own agents to the major immigrant destinations - New York, Chicago, Boston - and regional hubs such as Minneapolis-St. Paul and Kansas City or turned to employment agencies located in these places. ${ }^{24}$ David Bern- 
stein (1995) describes a parallel process of labor recruitment at work in the South. Throughout the late nineteenth century, employers in the relatively labor-scarce South Central region turned to emigrant agents operating in agricultural areas of the South Atlantic states to recruit additional labor. One indication of the impact that this recruitment had on population redistribution is the repeated efforts of state governments in the South Atlantic states to impose prohibitory licensing fees on labor recruiters.

Less is known about the forces that directed job-seekers setting off without the assistance of friends or family. Newspapers, guidebooks for immigrants, and more general word of mouth were presumably important factors influencing their decisions to migrate and their choices of destinations. Pioneering European immigrants were most likely to head for the major cities where employment agencies were concentrated and employers were most likely to send their agents. The decisions of employers and workers were mutually reinforcing. Job-seekers without specific information were most likely to go to the places with the highest concentration of potential employers, and employers were most likely to send their agents to the places with the greatest number of potential employees. Thus, while employer recruitment and worker job-search helped to create new channels of communication as the sources and destinations of labor changed, this process was also subject to a tendency toward path-dependence and historical lockin that helps to explain the failure of North-South integration within the United States.

As long as there was an adequate supply of immigrants, few northern employers felt a need to look to the South as a potential source of labor. Meanwhile, as long as labor demand in the South Central region remained relatively strong, the incentives for potential southern migrants to look to the North for employment were dulled. Only when European immigration was cut off as a result of the outbreak of World War I did northern employers begin to actively recruit for laborers in the South (Whatley 1990: 48-50). This shift in labor recruitment practices, which coincided with the widening North-South wage gap, is apparent in the rapid acceleration of net out-migration from the South beginning in the decade of the 1910s. William Collins (1997) argues that the black migration from the South began in earnest only during World War I because before that time foreign immigration "crowded out" black migration. According to this interpretation, employers' 
preference for white workers lowered the probability that black migrants would find employment and consequently offset much of the apparent regional wage gap. Only when competition from immigrants was eliminated was the difference in expected earnings large enough to justify large-scale migration to the North.

This account does not, however, explain why rates of net migration among southern whites also remained quite low in the pre-World War I era. ${ }^{25}$ More important, it is inconsistent with evidence about the role that labor agents and direct employer recruitment played in facilitating the flow of labor market information and thus initiating new streams of migration. As Warren Whatley (1990: 49) notes, the increase in black migration to the North during World War I was not an automatic response to existing earnings differentials. ${ }^{26}$ Rather, it required the creation of new labor market institutions to facilitate communication between employers and job-seekers and to provide financing for the costs of movement. In Alabama, for example, because of their railroad connections, the towns of Birmingham and Bessemer emerged as important meeting places where rural migrants and northern labor agents could find each other. In addition to directing migrants to northern employers, the agents also helped provide financing for their travel.

None of this implies that employers did not harbor racist views that caused them to discriminate against black job-seekers. But it does suggest that these attitudes influenced migration patterns primarily through recruiting practices. That northern employers continued to rely on well-established channels of immigrant recruitment tended, in turn, to reinforce employer prejudices, since few employers had had any direct experience with black employees that might have refuted their negative expectations. Only with the labor shortages caused by World War I did northern employers begin to invest in the development of labor recruitment channels in the South. As Whatley (1990) demonstrates, once this process was begun, the introduction of black workers into previously all-white firms generated new experiences within the firm that altered subsequent racial employment decisions.

There is no inherent economic reason why northern employers came to rely primarily on immigrant labor. Rather, the explanation is historical. Northern labor recruitment practices crystallized in the antebellum period. Prior to the Civil War, the dominant pattern of internal migration was 
from East to West (Steckel 1983). Initially, manufacturers in the Northeast recruited labor for their factories from among the surplus agricultural population created by increasing competition from more efficient midwestern farms (Field 1978). But by the 1840s, this source of labor was declining, while European immigration was increasing. North-South separation and northern reliance on immigrant labor was reinforced by the Civil War, and it was in these circumstances that late-nineteenth-century patterns of regional labor market integration emerged. These patterns persisted because southern job-seekers, especially in less skilled jobs, were unlikely to have personal contacts in the North who could provide them with information or assistance and because northern employers who might have wished to tap lower-wage southern labor sources lacked any well-developed mechanism to do so. Only when the existing patterns of labor recruitment were disrupted by the outbreak of World War I did northern employers begin to invest in developing the machinery to recruit southern job-seekers.

\section{Conclusion}

Wage and earnings data from the late nineteenth and early twentieth centuries show that labor markets were extensive but that integration was uneven and selective. In the decades after the Civil War, the links of labor markets across the northeastern and North Central United States with each other and with labor markets in Europe were increasingly close. At the same time, labor markets across the South were becoming increasingly integrated with each other, but they remained largely isolated from northern and international markets. This peculiar pattern of integration can be traced back to patterns of migration that emerged in the antebellum period and were subsequently reinforced by the path-dependent evolution of labor market institutions.

While the history of labor market integration is interesting in its own right, these conclusions are also important for a variety of other questions. Most important, they suggest that late-nineteenth-century labor history cannot be fully understood at the level of either the community or the nation. Labor market integration was not perfect, of course, and in the short run local conditions did matter, but in the longer run, communities were integrated into much broader markets, and this connection profoundly in- 
fluenced wage determination. Thus, the relatively slow growth of real wages in the United States compared to labor productivity in this period appears to be explained by the depressing effects of immigration on domestic wage levels. There is some evidence that the effects of this competition were greatest among unskilled workers, and the relative protection afforded to skilled workers may thus help to explain the apparent widening of skill differentials at this time. The competitive pressures created by the extension of labor markets also help to rationalize much of the rise in labor conflict in this period, as workers sought to preserve or enhance barriers that would protect them from competition.

How the course of American economic development would have differed in the absence of this immigration must remain speculative. But the findings of this article suggest that in the absence of a pool of European job-seekers, northern employers would likely have been much quicker to seek out low-wage southern workers and to establish channels of labor market recruitment similar to those that directed transatlantic migration before World War I. For northern workers it would probably have mattered little whether they faced competition from migrants from the low-wage South or from Europe. For the southern economy, however, integration into a broader national labor market would have had profound consequences. Instead of pursuing a distinctive low-wage path of development, as it actually did, the South would most likely have followed the same high-wage development path taken by the rest of the country.

\section{Notes}

Joshua L. Rosenbloom is an associate professor of economics at the University of Kansas and a research associate at the National Bureau of Economic Research. He is the author of numerous articles on late-nineteenth-century labor markets, including, most recently, "Strikebreaking and the Labor Market in the United States, 1881-1894," Fournal of Economic History 58, no. 1, and is writing a book on the geographic integration of U.S. labor markets during the late nineteenth and early twentieth centuries. He wishes to thank Gavin Wright, Tom Weiss, Greg Hess, and three anonymous referees for their comments. His research was supported in part by an Arthur Cole grant from the Economic History Association and by University of Kansas General Research Fund Allocations \#3899-20-0038 and \#3904-20-0038.

1 The role of market expansion figures prominently in most accounts of European economic growth as well. See North 1981 and Rosenberg and Birdzell 1986: chap. 3 
for recent examples. McCloskey (1995: 4) argues that "the extent of the market is the central descriptive question in economic history."

2 There have been a number of studies of interregional and international wage variation, but these have generally been confined to an examination of a single source of wage data rather than offering a comprehensive account of labor market integration. On variation within the United States see Coelho and Shepherd 1976, 1979; Rosenbloom 1990a, 1991, 1996; and Sundstrom and Rosenbloom 1993. Allen 1994 and Williamson 1995 offer the most extensive efforts at international wage comparisons.

3 David (1986: 41-43) discusses the conditions under which path-dependent behavior will arise.

4 Implicitly, I am also assuming that there are no costs associated with transactions between employers and job-seekers within each location.

5 It is worth noting that many of these costs of movement are not uniquely determined but will depend on historical and institutional details. For example, the costs of passage between two locations are likely to be influenced by the volume and nature of trade between these places. In the late nineteenth century, steamship companies offered low fares for steerage passengers from Europe to the United States to fill space occupied in the other direction by bulk cargoes such as American farm products.

6 It should also be noted that where wages are equalized without integration, the absence of integration is not particularly significant: It does not produce any inefficiencies in the spatial allocation of labor.

7 See Long 1960: 7-12 for further discussion of these sources.

8 The six occupations are engineers, blacksmiths, machinists, painters, carpenters, and common laborers. Because each observation in their data represents the average wage for a particular occupation paid by a particular employer and the mix of occupations across regions may differ, regional average wages will reflect differences in occupational mix as well as differences in earnings within occupations. To control for differences in occupational composition across regions, Coelho and Shepherd regressed each wage observation on region and occupation dummy variables and used the coefficient on the region dummy to measure interregional earnings differences.

9 These results are broadly consistent with Margo's (1992: 190-92) analysis of antebellum regional wage differentials based on wage data for civilian employees at military forts from 1820 to 1860 , which finds that real wages of artisans and laborers in the Midwest were higher than those of comparable workers in the East but that there was a gradual tendency toward convergence.

10 The Aldrich Report also included retrospective wage data for New England and the Middle Atlantic region but not for other parts of the country.

11 Until 1905 the Census Bureau defined the census year for manufacturing data to be the 12 months ending on 31 May of the census year, but firms were allowed to submit reports for the business year coinciding most closely with the census year. In most cases the reported data seem to pertain to the preceding calendar year. 
Reflecting this practice, beginning with the 1905 census, the census year was shifted to coincide with the previous calendar year, and greater efforts were made to ensure that all firms reported statistics for this period (Easterlin 1957: 679-80). There were a number of changes in census concepts and methods over time, but in Rosenbloom 1996 (630-34) I argue that the impact of these changes on interregional differentials was negligible.

12 In Rosenbloom 1996 I controlled for the proportion of the labor force in two of the numerically most important groups of skilled occupations-construction and metalworking - as well as the proportion of unskilled laborers.

13 The coefficient of variation normalizes the standard deviation of wages across cities within each region by expressing it as a fraction of the average wage within the region.

14 Prior to the second half of the nineteenth century the only comparable intercontinental migration was the forced movement of black slaves from Africa to the Americas and the Caribbean (Hatton and Williamson 1994a: 4).

15 Hatton and Williamson (1994a: 8-15) review the literature on this subject in greater depth.

16 Taylor and Williamson (1994) and O'Rourke, Williamson, and Hatton (1994) argue that this convergence would have been even more pronounced had international capital markets been less integrated. The parallel flow of capital from Europe to the New World helped to offset the effects of migration on the capital-labor ratio in both the Old and New Worlds and thus reduced the effects of labor movements on the wage gap.

17 In principle, international wage convergence could have been achieved without labor market integration through the effects of factor price equalization. The large magnitude of population flows at this time suggests, however, that factor price equalization cannot be the whole story. General equilibrium analysis also suggests that factor price equalization was not a major factor in wage equalization at this time (Williamson 1996: 285-88).

18 It is conceivable, of course, that the North-South wage gap is simply the result of measurement errors. But such an interpretation seems unlikely given the fact that interregional wage differentials are clearly present in several independent sources of occupational wage data, as well as in average annual earnings.

19 This point is made by Wright (1986: 71).

20 Arguing that the observed wage gap overstated the economic incentives to migration requires identifying some nonpecuniary aspect of compensation that offset the observed wage differential. This would be the case, for example, if southern workers received nonpecuniary benefits that northern workers did not. Alston and Ferrie $(1989,1993)$ have argued that planter paternalism provided tenants and sharecroppers with a wide range of services that should be regarded as a form of additional compensation. Paternalism also served to reduce mobility because planters used their authority to reward their more stable tenants. This explanation might help 


\section{Social Science History}

to account for the North-South gap in farm wages and could also be a factor in explaining gaps between farm and nonfarm wages within the South, but since paternalism was not a factor in urban employment relationships, it does not appear capable of explaining the gap in urban craft and industrial wages and earnings between North and South documented in this article. It is also incapable of accounting for the observed fluctuations in the rate of out-migration from the South, especially the substantial increase in out-migration that occurred during and after World War I. Alternatively, high northern wages might be offset by some nonwage costs. Collins (1997), for example, argued that northern employers' preferences for European immigrants reduced employment opportunities for southern blacks prior to World War I and thus lowered expected earnings. While I agree with a number of aspects of Collins's argument, it fails to account for the migration patterns of southern whites, as I argue in more detail below.

21 See, for example, Kamphoefner 1987, Gjerde 1985, Barton 1975, MacDonald and MacDonald 1974, Morawska 1990, Gould 1979, and Hareven 1982.

22 A 1936 study of 2,500 Philadelphia workers conducted by Gladys Palmer and recently analyzed by Walter Licht (1992: 31-40) asked for retrospective information on the respondents' entire employment histories. In a number of cases these stretched back into the $1880 \mathrm{~s}$. In this survey, $50 \%$ of those interviewed reported finding their first job through a friend or relative, while $44 \%$ reported using this method to find subsequent jobs. Hareven (1982) reaches a similar conclusion about workers in the textile factories of Amoskeag, NH. In Rosenbloom 1994 I cite a wide range of more recent surveys consistent with this conclusion.

23 Montgomery (1991) offers a theoretical model illustrating the way in which reliance on employee references can emerge as the preferred method of recruitment and job-seeking.

24 On the evolution of employment agencies see Rosenbloom 1990b.

25 Most of the available evidence suggests that while there was substantial occupational segregation within the South, racial differences in unskilled wage rates were small or nonexistent. Thus, even if measured interregional wage differentials overstate the incentives for potential black migrants, they should be an accurate index of the incentives facing unskilled white workers in the South (Wright 1986: 182-86; Whatley 1990: 50-51).

26 Margo's (1990: 116-17) analysis of black migration indicates that while rising education levels can account for the small increase in migration from the South between 1900 and 1910, the sharp increase in out-migration between 1910 and 1920 is largely unexplained and must be attributed to exogenous shocks. 


\section{References}

Allen, Robert C. (1994) "Real incomes in the English-speaking world, 1879-1913," in George Grantham and Mary MacKinnon (eds.) Labour Market Evolution: The Economic History of Market Integration, Wage Flexibility and the Employment Relation. London and New York: Routledge: 107-38.

Alston, Lee J., and Joseph P. Ferrie (1989) "Social control and labor relations in the American South before the mechanization of the cotton harvest in the 1950s." Journal of Institutional and Theoretical Economics 145: 133-57.

- (1993) "Paternalism in agricultural labor contracts in the U.S. South: Implications for the growth of the welfare state." American Economic Review 83: 852-76.

Barton, Josef J. (1975) Peasants and Strangers: Italians, Rumanians, and Slovaks in an American City, 1890-1950. Cambridge: Harvard University Press.

Ben-Porath, Yoram (1980) "The F-connection: Families, friends, and firms in the organization of exchange." Population and Development Review 6: 1-30.

Bernstein, David E. (1995) "The law and economics of post-Civil War restrictions on interstate migration by African Americans." George Mason University, School of Law. Law and Economics Working Paper Series no. 96-03.

Bodnar, John (1985) The Transplanted: A History of Immigrants in Urban America. Bloomington: Indiana University Press.

Chandler, Alfred D., Jr. (1977) The Visible Hand: The Managerial Revolution in American Business. Cambridge: Harvard University Press.

Coelho, Philip R. P., and James F. Shepherd (1976) "Regional differences in real wages: The United States, 1851-1880." Explorations in Economic History 13: 203-30.

- (1979) "The impact of regional differences in prices and wages on economic growth: The United States in 1890." Journal of Economic History 39: 69-85.

Collins, William J. (1997) "When the tide turned: Immigration and the delay of the great migration." Journal of Economic History 57: 607-32.

David, Paul A. (1986) "Understanding the economics of QWERTY: The necessity of history," in William N. Parker (ed.) Economic History and the Modern Economist. Oxford: Basil Blackwell: 30-49.

Dunlevy, James A. (1980) "Nineteenth-century European immigration to the United States: Intended versus lifetime settlement patterns." Economic Development and Cultural Change 29: 77-90.

Dunlevy, James A., and Henry A. Gemery (1978) "Economic opportunity and the response of 'old' and 'new' migrants to the United States." Journal of Economic History 38: 901-18.

Dunlevy, James A., and Richard P. Saba (1992) "The role of nationality-specific characteristics on the settlement patterns of late-nineteenth-century immigrants." Explorations in Economic History 29: 228-49.

Easterlin, Richard A., and Everett S. Lee (1957) "Estimates of manufacturing activity," in Simon S. Kuznets and Dorothy Swaine Thomas (eds.) Population Redistribution 
and Economic Growth, United States, 1870-1950. Vol. 1, Methodological Considerations and Reference Tables. Philadelphia: American Philosophical Society: 635-702.

Eldridge, Hope T., and Dorothy Swaine Thomas (1964) Population Redistribution and Economic Growth, United States, 1870-1950. Vol. 3, Demographic Analyses and Interrelations. Philadelphia: American Philosophical Society.

Field, Alexander James (1978) "Sectoral shifts in antebellum Massachusetts: A reconsideration." Explorations in Economic History 15: 146-71.

Gjerde, John (1985) From Peasants to Farmers: Migration from Balestrand, Norway, to the Upper Middle West. Cambridge: Cambridge University Press.

Goldin, Claudia (1990) Understanding the Gender Gap: An Economic History of American Women. New York: Oxford University Press.

Gordon, David M., Richard Edwards, and Michael Reich (1982) Segmented Work, Divided Workers: The Historical Transformation of Labor in the United States. Cambridge: Cambridge University Press.

Gould, J. D. (1979) "European inter-continental emigration, 1815-1914: Patterns and causes." Journal of European Economic History 8: 593-679.

Hareven, Tamara K. (1982) Family Time and Industrial Time: The Relationship between the Family and Work in a New England Industrial Community. Cambridge: Cambridge University Press.

Hatton, Timothy J., and Jeffrey G. Williamson (1994a) "International migration, 18501939: An economic survey," in Timothy Hatton and Jeffrey G. Williamson (eds.) Migration and the International Labor Market, 1850-1939. New York and London: Routledge: 3-32.

(1994b) "What drove the mass migrations from Europe in the late nineteenth century." Population and Development Review 20: 533-59.

(1995) "The impact of immigration on American labor markets prior to the quotas." National Bureau of Economic Research Working Paper no. 5185.

James, John A. (1978) Money and Capital Markets in Postbellum America. Princeton, NJ: Princeton University Press.

Jerome, Harry (1926) Migration and Business Cycles. New York: National Bureau of Economic Research.

Kamphoefner, Walter D. (1987) The Westfalians: From Germany to Missouri. Princeton, NJ: Princeton University Press.

Lebergott, Stanley (1964) Manpower in Economic Growth: The American Record since 1800. New York: McGraw-Hill.

Licht, Walter (1992) Getting Work: Philadelphia, 1840-1950. Cambridge: Harvard University Press.

Long, Clarence D. (1960) Wages and Earnings in the United States, 1860-1890. National Bureau of Economic Research, General Series, no. 67. Princeton, NJ: Princeton University Press.

MacDonald, John S., and Leatrice D. MacDonald (1974) "Chain migration, ethnic 
neighborhood formation, and social networks," in Charles Tilly (ed.) An Urban World. Boston: Little, Brown: 226-36.

Madden, Carl (1956) "Some spatial aspects of urban growth in the United States." Economic Development and Cultural Change 4: 371-87.

Maddison, Angus (1991) Dynamic Forces in Capitalist Development. New York: Oxford University Press.

Margo, Robert A. (1990) Race and Schooling in the American South, 1880-1950: An Economic History. Chicago: University of Chicago Press.

(1992) "Wages and prices during the antebellum period: A survey and new evidence," in Robert E. Gallman and John Joseph Wallis (eds.) American Economic Growth and Standards of Living before the Civil War. Chicago: University of Chicago Press: 173-210.

Marshall, Alfred (1920) Principles of Economics, 8th ed. London: Macmillan.

McCloskey, Donald N. (1995) "The extent of the market and the faculty of speech." Photocopy, University of Iowa.

Montgomery, James D. (1991) "Social networks and labor-market outcomes: Toward an economic analysis." American Economic Review 81: 1408-18.

Morawska, Ewa (1990) "The sociology and historiography of immigration," in Virginia Yans-McLaughlin (ed.) Immigration Reconsidered: History, Sociology, and Politics. New York: Oxford University Press: 187-238.

Myrdal, Gunnar (1944) An American Dilemma: The Negro Problem and Modern Democracy. New York: Harper \& Brothers.

North, Douglass C. (1981) Structure and Change in Economic History. New York: W.W. Norton.

O'Rourke, Kevin, Jeffrey G. Williamson, and Timothy J. Hatton (1994) "Mass migration, commodity market integration, and real wage convergence: The late-nineteenthcentury Atlantic economy," in Timothy J. Hatton and Jeffrey G. Williamson (eds.) Migration and the International Labor Market, 1850-1939. New York and London: Routledge: $203-220$.

Perloff, Harvey S., et al. (1965) Regions, Resources, and Economic Growth. Lincoln: University of Nebraska Press.

Rosenberg, Nathan, and L. E. Birdzell Jr. (1986) How the West Grew Rich. New York: Basic Books.

Rosenbloom, Joshua L. (1988) "Labor market institutions and the geographic integration of labor markets in the United States." Ph.D. diss., Stanford University.

(1990a) "One market or many?: Labor market integration in the late-nineteenthcentury United States." Journal of Economic History 50: 85-107.

(1990b) "Employment agencies and labor exchanges before the First World War: An examination of the methods of labor market adjustment." Photocopy, University of Kansas.

(1991) "Occupational differences in labor market integration: The United States in 1890." Journal of Economic History 51: 427-39. 
(1994) "Looking for work, searching for workers: U.S. labor markets after the Civil War." Social Science History 18: 377-403.

(1996) "Was there a national labor market at the end of the nineteenth century?:

New evidence on earnings in manufacturing." Journal of Economic History 56 : 626-56.

Shergold, Peter R. (1983) "'Reefs of roast beef': The American worker's standard of living in comparative perspective," in Dirk Hoerder (ed.) American Labor and Immigration History, 1877-1920s: Recent European Research. Urbana: University of Illinois Press: 78-105.

Steckel, Richard (1983) "The economic foundations of East-West migration during the nineteenth century." Explorations in Economic History 20: 14-36.

Sundstrom, William A., and Joshua L. Rosenbloom (1993) "Occupational differences in the dispersion of wages and working hours: Labor market integration in the United States, 1890-1903." Explorations in Economic History 30: 379-408.

Taylor, Alan M., and Jeffrey G. Williamson (1994) "Convergence in the age of mass migration." National Bureau of Economic Research Working Paper no. 4711.

Thomas, Brinley (1954) Migration and Economic Growth. Cambridge: Cambridge University Press.

Tilly, Charles (1990) “Transplanted networks," in Virginia Yans-McLaughlin (ed.) Immigration Reconsidered: History, Sociology, and Politics. New York: Oxford University Press: 79-95.

U.S. Congress, House of Representatives (1886) Report on the Statistics of Wages in Manufacturing with Supplementary Reports. Joseph D. Weeks. House Misc. Doc. 42, vol. 13, part 20, 47th Cong., 2d sess. Washington: GPO.

U.S. Congress, Senate (1892) Retail Prices and Wages. Senate Report no. 986, 52d Cong., 1st sess., 3 parts. Washington: GPO.

U.S. Department of Commerce and Labor (1905) Nineteenth Annual Report of the Commissioner of Labor, 1904, "Wages and hours of labor." Washington: GPO.

U.S. Department of Labor (1898) "Wages in the United States and Europe, 1870 to 1898." Bulletin of the Department of Labor, no. 18: 665-93.

Whatley, Warren C. (1990) "Getting a foot in the door: 'Learning,' state dependence, and the racial integration of firms." Journal of Economic History 50: 43-60.

Williamson, Jeffrey G. (1995) "The evolution of global labor markets since 1830: Background evidence and hypotheses." Explorations in Economic History 32: 141-96.

- (1996) "Globalization, convergence, and history." Journal of Economic History 56: 277-306.

Wright, Gavin (1986) Old South, New South: Revolutions in the Southern Economy since the Civil War. New York: Basic Books. 